\title{
Chemical constituents, antioxidant and anti-lipase activity of some wines produced in Georgia
}

\section{Levan Gulua ${ }^{1}$, Lika Nikolaishvili ${ }^{1}$, Tamar Turmanidze ${ }^{1}$, Merab Jgenti ${ }^{1}$, Marine Bezhuashvili ${ }^{1}$, Roger FitzGerald ${ }^{2}$}

\author{
1 - Agricultural University of Georgia, Tbilisi, Georgia \\ 2 - University of Limerick, Limerick, Ireland
}

Keywords:

Wine

Anti-lipase

Activity

Antioxidant

Polyphenols

Georgia

Article history:

Received 24.04.2018

Received in revised

form 16.06.2018

Accepted 29.06.2018

\section{Corresponding \\ author:}

Tamar Turmanidze

E-mail:

tturm2010@

agruni.edu.ge

DOI: $10.24263 / 2304-$

974X-2018-7-2-3

\section{Abstract}

Introduction. The purpose of this work was to investigate the composition, in vitro antioxidant and antilipase activity of different types of wine produced in Georgia and to identify the relationship, if any, between anti-lipase activity, polyphenol content and the antioxidant activity of the wines.

Materials and methods. Individual polyphenols were separated and quantified by HPLC analysis performed using a liquid chromatograph (Varian Prostar 500, Walnut Creek, California, USA). One unit of lipase activity was defined as that amount of lipase which hydrolyses 1.0 micro equivalent of fatty acid from a triglyceride in one hour at $\mathrm{pH} 7.2$ at $37^{\circ} \mathrm{C}$. Ferric reducing ability of plasma (FRAP) assay was applied in order to determine antioxidant activity. All other methods used are standard biochemical methods.

Results and discussion. This study investigated the composition, antioxidant and anti-lipase activity of 6 different wines (Saperavi 2016, Saperavi 2017, Tavkveri 2017, Cabernet Franc 2017, 5. Cabernet Sauvignon 2017 and 6. Rkatsiteli 2017) produced in Georgia. Highest polyphenol content was found in Cabernet Sauvignon 2017 and Cabernet Franc $2017 \quad(1843.13 \pm 92.15$ and $1650.82 \pm 82.50 \mathrm{mg} \mathrm{L}^{-1}$, respectively) while Rkatsiteli 2017 had the lowest polyphenol content $\left(1046.42 \pm 52.30 \mathrm{mg} \mathrm{L}^{-1}\right)$. Malvidin-3-O-monoglucoside content, expressed as a percentage of total monoglucosides, ranged from 48.12 to 68.58\%. Cabernet Sauvignon 2017 and Cabernet Franc 2017 had highest antioxidant (FRAP) activity, i.e., $2189.05 \pm 109.45$ and $1973.09 \pm 98.65 \mathrm{mg}$ ascorbic acid equivalents $\mathrm{L}^{-1}$, respectively. Cabernet Sauvignon 2017 and Cabernet Franc 2017 also displayed the highest level of pancreatic lipase inhibitory activity (79.7 and 78.7\% inhibition $\mathrm{mL}^{-1}$ of wine, respectively). Rkatsiteli 2017 and Tavkveri 2017 had the lowest anti-lipase activity (58.1 and $56.6 \%$ inhibition $\mathrm{mL}^{-1}$, respectively).

Conclusion. Georgian wines represent natural sources of phytochemicals with high levels of antioxidant and antilipase activity. 


\section{Introduction}

Obesity is a now a severe public health problem in all industrialised countries. According to the World Health Organization, worldwide obesity has nearly tripled since 1975. In 2016 it was shown that over 1.9 billion adults were overweight over 650 million of which were considered to be obese [1]. Obesity is frequently associated with the intake of a lipid-rich diet. Pancreatic lipase (triacylglycerol acyl hydrolase EC 3.1.1.3) is an enzyme which plays a central role in lipid digestion and subsequent absorption in humans. Consequently, dietary lipid absorption can be reduced by the partial inhibition of lipase activity and this is currently one of the main strategies used in the management and treatment of obesity [2-4]. Large numbers of plants have been screened for the purpose of discovering naturally occurring potent lipase inhibitors [5-7]. Foodstuffs such as cereals, soybeans, medicinal plants, grapes, green tea and leguminous plants have been shown to contain a range of phytochemicals with anti-lipase activity [8-15]. Phytochemicals such as alkaloids, carotenoids, glycosides, polysaccharides, saponins, terpenes and polyphenols have been shown to possess anti-lipase activity [4, 16-24]. Nevertheless, Orlistat ${ }^{\circledR}$ (Xenical), an hydrogenated derivative of lipstatin isolated from the Gram-positive bacterium Streptomyces toxytricini, is currently the only pancreatic lipase inhibitor in clinical use for the management and treatment of obesity. However, the ingestion of this compound is associated with a number of adverse effects such as liquid stools, diarrhea, steatorrhea fecal urgency, etc, which significantly limits its use as a general medication [25-30]. Therefore, a clear need exists to discover other naturally derived sources of phytochemicals with potent anti-lipase activity.

In this context, Georgian wines are known to contain high levels of polyphenols and therefore may be considered as potential natural inhibitors of pancreatic lipase. The total polyphenol content in Georgian white wines produced using the unique Kakhetian technology was reported to be between 2000 and $2290 \mathrm{mg} \mathrm{L}^{-1}$. In red wines the total polyphenol content ranged between $2848-4416 \mathrm{mg}$ per liter [31]. Winemaking in Georgia dates back to the early sixth millennium BC and Georgia is believed to be a cradle of wine [32].Wine consumption has traditionally played a significant role in the dietary regime of Georgians. Consumption of wine and its associated chemical constituents in the everyday diet of Georgians has been linked to many beneficial and well-known health promoting properties, particularly their anti-lipase activity [31, 33]. However, while a significant amount of research has been performed on Georgian wines [34-36], no data appears to exits on their anti-lipase activity. Therefore, the acquisition of detailed information about Georgia's traditional winemaking and wine consumption may be useful in revealing the role of wine consumption in reducing the consequences of high fat diets in humans. Additionally, it has been well documented that oxidative stress is associated with obesity [37]. Therefore, consumption of polyphenolic rich wine may also help alleviate the effects of oxidative stress.

The objective of this work was to investigate the composition, in vitro antioxidant and anti-lipase activity of different types of wine produced in Georgia and to identify the relationship, if any, between anti-lipase activity, polyphenol content and the antioxidant activity of the wines. 


\section{Materials and methods}

\section{Grapes and wines}

Six wines produced in Georgia were chosen for investigation The grapes used for the manufacture of the different wines were harvested in September-October from the following locations in Georgia: Saperavi 2016 from Gurjaani $\left(41^{\circ} 44 ' 34.51^{\prime \prime} \mathrm{N} 45^{\circ} 48^{\prime} 4.00^{\prime \prime}\right.$

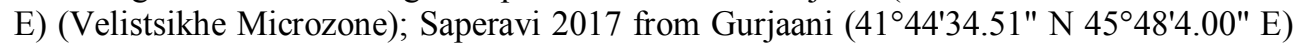

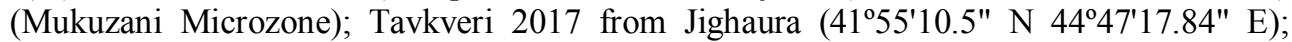

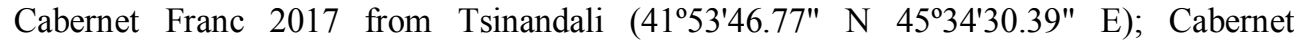

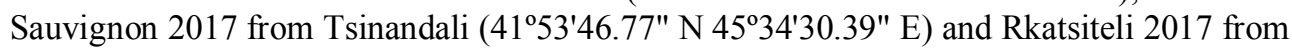
Gurjaani (41 $44^{\prime} 34.51^{\prime \prime} \mathrm{N} 45^{\circ} 48^{\prime} 4.00^{\prime \prime}$ E) (Velistsikhe Microzone).

Saperavi 2017, Tavkveri 2017, Cabernet Franc 2017 and Cabernet Sauvignon 2017 were produced according to the traditional Georgian technology as previously described Navarre et al, 2017 [38], at the experimental winemaking plant of the Agricultural University of Georgia. Saperavi 2016 was produced according to the Georgian Kakhetian technology and Rkatsiteli 2017 according to the Kakhetian Qvevri technology. Grapes along other parts of the grape, i.e., cluster (stem, skin, seeds) were crushed in a juicer and were then placed in a fermentation vessel. The traditional Qvevri technology involves placing a clay vessel in the ground following procedure are described by Shalashvili et al, 2012 [35].

\section{Chemicals}

Ascorbic acid, olive oil, sodium hydroxide, potassium dihydrogen phosphate, HPLCgrade ethyl acetate and methanol were purchased from Sigma Aldrich (Steinheim, Germany). 2,4,6-Tris (2-pyridyl)-s-triazine (TPTZ) was purchased from Sigma Aldrich (Steinheim, Germany). Folin-Ciocalteu reagent was from Appli Chem ( Steinheim, Germany). Hydrochloric acid, formic acid and phosphoric acid were provided from Merck (Darmstadt, Germany). Sodium carbonate was from Chem Cruz Biochemicals (California, USA). Tween 80 detergent was obtained from Ferak Berlin GmbH (Berlin, Germany). Pancreatic plant lipase concentrate was purchased from Integrative Therapeutics, (Green Bay, USA). Orlistat ${ }^{\circledR}$ (trade name Xenical) manufactured by Roche (Italy) was purchased at a local pharmacy. All other reagents were commercially available at the local market and were of analytical grade.

\section{Sample preparation for chemical analyses}

Sample preparation for individual anthocyanin analysis. An aliquot $(2.0 \mathrm{~mL})$ of the different wine samples was carefully deposited onto a $\mathrm{C} 18$ solid phase extraction cartridge (Agilent, Bond Elut, USA). Sugars and more polar substances were eluted using $2.0 \mathrm{~mL}$ of ultrapure water through the cartridge. Polyphenols were eluted using $2.0 \mathrm{~mL}$ of ethyl acetate and finally anthocyanin pigments were eluted with $10 \mathrm{~mL}$ of methanol. Deionized water (DI, $10 \mathrm{~mL}$ ) was added to the methanol extract and the methanol was then removed under vacuum in a rotary evaporator operating at $<30^{\circ} \mathrm{C}$.

Sample preparation for individual polyphenol analysis. An aliquot $(4.0 \mathrm{~mL})$ of the wine sample was carefully deposited onto a C18 solid phase extraction cartridge (Agilent, Bond Elut, USA). Sugars and more polar substances were eluted using $2.0 \mathrm{~mL}$ of ultrapure 
water through the cartridge. Polyphenols were eluted using $2.0 \mathrm{~mL}$ of ethyl acetate. Ethyl acetate was evaporated under vacuum at $40-45^{\circ} \mathrm{C}$. Four $\mathrm{mL}$ of $50 \%$ ethanol was added to the dry extract. The extract was filtered through $45 \mu \mathrm{m}$ filter paper (Whatman, Maidstone, $\mathrm{UK}$ ) and $20 \mu \mathrm{L}$ was injected onto the high performance liquid chromatography (HPLC) system.

Titratable acidity. Titratable acidity (TA) was determined by titration with $0.1 \mathrm{~N}$ sodium hydroxide using an automatic titrator (ZDJ-4A, INESA Scientific Instrument Co., Ltd, Anting Shanghai, China). The TA results were expressed as g of tartaric acid equivalents $100 \mathrm{~mL}^{-1}$ of sample [39].

Total dry matter. For measurement of nonvolatile dry matter in wines a $50 \mathrm{~mL}$ sample of wine was aliquoted into a porcelain dish. The dish was then placed in a boiling water bath until evaporation of water, alcohol and other volatile compounds had occurred. Residual moisture was then evaporated from the samples by oven drying at $105{ }^{\circ} \mathrm{C}$ for $16 \mathrm{~h}$. Total dry matter was determined gravimetrically as the residue remaining after drying.

Alcohol content. The alcoholic strength by volume of the different wines was determined by distillation as described in Method OIV MA AS312 01A in the Compendium of International Analysis Methods [40].

Ferric reducing ability of plasma (FRAP) assay. The antioxidant capacity of the different wines was determined following the procedure described by Benzie et al, 1996 [41] with minor modifications. The FRAP reagent was freshly prepared by adding $10 \mathrm{mM}$ 2,4,6-tripyridyl-s-triazine (TPTZ) (dissolved in $40 \mathrm{mM} \mathrm{HCl}$ ), $20 \mathrm{mM}$ of Iron (III) chloride in water and $300 \mathrm{mM}$ of sodium acetate buffer $(\mathrm{pH} 3.6)$ in the ratio 1:1:10. The FRAP reagent was heated at $37{ }^{\circ} \mathrm{C}$ for $15 \mathrm{~min}$. Then $100 \mu \mathrm{L}$ of wine sample was added to $3.0 \mathrm{~mL}$ FRAP reagent (blank). The absorbance was recorded at $593 \mathrm{~nm}$. The reaction was monitored for $4 \mathrm{~min}$. FRAP values of the samples were compared to that of ascorbic acid and were expressed as mg of ascorbic acid equivalents (AAE) $\mathrm{L}^{-1}$ of wine.

Determination of total phenolic compounds (TPC). Determination of TPC was performed according the method of Bond et al, 2003[42]. The samples and standards (gallic acid standard solutions $10-50 \mu \mathrm{g} \mathrm{mL}^{-1}$ ) were equilibrated at room temperature for $60 \mathrm{~min}$ prior to analysis. An aliquot of $1.0 \mathrm{~mL}$ of appropriately diluted (with DI water) sample was vortexed with $10 \mathrm{~mL}$ distilled water and $1.0 \mathrm{~mL}$ Folin-Ciocalteau reagent. DI water (1.0 $\mathrm{mL}$ ) was used as a control. After equilibration at room temperature for $8 \mathrm{~min}$, the solutions were mixed with $4 \mathrm{~mL}$ of $7.5 \%(\mathrm{w} / \mathrm{v})$ sodium carbonate. The absorbance of the samples and standards were measured spectrophotometrically (UV/Vis spectrophotometer, AE UV1609, A \& E Lab Instruments Co., Ltd. Guangzhou, China) at $765 \mathrm{~nm}$, with a $10 \mathrm{~mm}$ path length cell. TPC was calculated as $\mathrm{mg}$ of gallic acid equivalents (GAE) $100 \mathrm{~mL}^{-1}$ of sample.

Determination of individual polyphenols. Individual polyphenols were separated and quantified by HPLC analysis performed using a Varian Prostar 500 series liquid chromatograph (Varian Prostar 500,Walnut Creek, California, USA). Separation was achieved on a C18, $150 \mathrm{~mm} \times 4.6 \mathrm{~mm}$ column (Waters Corporation, Milford, USA). Solvent A was $0.5 \%$ acetic acid and solvent B was $100 \%$ methanol. Separation was achieved using the following gradient: isocratic $0 \% \mathrm{~B}$ and $100 \% \mathrm{~A}$ for $0 \mathrm{~min}$; isocratic $40 \%$ 
$\mathrm{B}$ and $60 \% \mathrm{~A}$ over $40 \mathrm{~min} ; 0 \% \mathrm{~B}$ and $100 \% \mathrm{~A}$ over $10 \mathrm{~min} ; 0 \% \mathrm{~B}$ and $100 \% \mathrm{~A}$ over 10 $\mathrm{min}$. The flow rate was $0.5 \mathrm{~mL} \mathrm{~min}^{-1}$ and eluent was monitored at $280 \mathrm{~nm}$.

Determination of the content of monomeric anthocyanins. Anthocyanins were quantified using the $\mathrm{pH}$ differential method described by Giusti et al, 2001 [43]. Wine samples were diluted 1:50 in $\mathrm{pH} 1.0$ and $\mathrm{pH} 4.5$ buffers, and the absorbance measured at $520 \mathrm{~nm}$ and $700 \mathrm{~nm}$ in a UV -Visible spectrophotometer (A \& E Lab Co Ltd., Guangzhou, China).The molar extinction coefficient used for cyanidin 3-glucoside was $26,900 \Delta \mathrm{E} / \mathrm{mole}$ at $510 \mathrm{~nm}$ having a molecular mass of $449.2 \mathrm{~g} / \mathrm{mole}$ The results were expressed in terms of $\mathrm{mg}$ of anthocyanin $\mathrm{L}^{-1}$ of wine [43].

Determination of individual anthocyanins using liquid chromatography mass spectrometry (LC-MS). HPLC analyses was performed using a Varian Prostar 500 series liquid chromatography system. Separation was achieved using a C18, $150 \mathrm{~mm} \bullet 4.6 \mathrm{~mm}$ column (Waters Corporation, Milford, USA). Solvent A was $0.1 \%$ aqueous formic acid (FA) and solvent B was $100 \%$ methanol. Separation was achieved using the following gradient: isocratic $6 \% \mathrm{~B}$ for $5 \mathrm{~min}, 30 \% \mathrm{~B}$ over $10 \mathrm{~min}$, isocratic $50 \% \mathrm{~B}$ for $15 \mathrm{~min}, 60 \% \mathrm{~B}$ over $5 \mathrm{~min}$ and $6 \% \mathrm{~B}$ over $10 \mathrm{~min}$ at a flow rate of $0.4 \mathrm{~mL} \mathrm{~min}^{-1}$. Detector response was monitored at $518 \mathrm{~nm}$. The MS was equipped with an electro spray ionization (ESI) source and an ion trap mass analyzer (Varian Prostar 500, Walnut Creek, California, USA). Mass spectra were recorded in positive ion mode at 3500 volts. The content of the different anthocyanin percentage was quantified based on the peak areas detected at $518 \mathrm{~nm}$. Individual anthocyanins were identified according to their mass spectra.

Determination of lipase activity. The procedure employed for determination of lipase activity was essentially as reported by Stoytcheva et al, 2012 [44] with minor modifications. Briefly, the initial reaction mixture consisted of $2.5 \mathrm{~mL}$ deionized water, 3 $\mathrm{mL}$ of olive oil, $1 \mathrm{~mL} 200 \mathrm{mM}$ Tris $\mathrm{HCl}$ buffer (pH 7.2) and $0.5 \mathrm{~mL}$ detergent (Tween 80). The mixture was mixed rigorously using a magnetic stirrer for $15 \mathrm{~min}$ in order to obtain a good emulsion. The lipase preparation $(150 \mathrm{mg})$ was then added to the emulsified mixture and incubated at $37{ }^{\circ} \mathrm{C}$ for $30 \mathrm{~min}$. At the end of incubation, $3 \mathrm{~mL}$ of $95 \%$ alcohol was added and the final reaction mixture was titrated with $50 \mathrm{mM} \mathrm{NaOH}$ using an automatic potentiometric titrator (ZDJ-4A, INESA Scientific Instrument Co., Ltd, Anting Shanghai, China). The end point for the titration was set at $\mathrm{pH}$ 9.0. A blank titration was carried out as above but without lipase. One unit of lipase activity was defined at that amount of lipase which hydrolyses 1.0 micro equivalent of fatty acid from a triglyceride in one hour at $\mathrm{pH}$ 7.2 at $37^{\circ} \mathrm{C}$. Lipase activity was calculated according to the following formula:

$$
\text { Lipase Units }=(\mathrm{A}-\mathrm{B}) \cdot 1000 \cdot 2 \cdot \mathrm{DF}
$$

where $\mathrm{A}=$ volume of $50 \mathrm{mM} \mathrm{NaOH}$ consumed by the test sample in $\mathrm{mL}$

$\mathrm{B}=$ volume of $50 \mathrm{mM} \mathrm{NaOH}$ consumed by the blank sample in $\mathrm{mL}$

$1000=$ conversion factor from milli equivalents to micro equivalents

$2=$ time conversion factor from $30 \mathrm{~min}$ to $1 \mathrm{~h}$

$\mathrm{DF}=$ dilution factor

The lipase inhibitory activity of the different wines was assessed following addition of $1 \mathrm{ml}$ of wine to the reaction mixture described above. The reaction and subsequent titration was performed as described above for the determination of lipase activity. The percentage 


\section{- Food Technology -}

inhibition was calculated from the lipase activity obtained in the presence and absence of wine and was calculated both per $\mathrm{mL}$ of wine as well as per $\mathrm{mg}$ of non-volatile dry extract of wine. Orlistat $(20 \mathrm{mg})$ was used as a standard inhibitor compound. Lipase activity was measured in the presence of Orlistat and the percentage inhibition was calculated $\mathrm{mg}^{-1}$ of Orlistat.

\section{Statistical analysis}

The data presented represents the mean of three replicates \pm standard deviation (SD). Data were subjected to the one-way ANOVA and Tukey's HSD tests. All calculations were performed with Microsoft Excel 2007 (Microsoft Corp., Redmond, WA, USA) with PHstat 2 version 3.11 add-in assistance.

\section{Results and discussion}

The wines studied herein are named according to the varieties of grapevine from which they were produced. Rkatsiteli, Saperavi and Tavkveri are native Georgian varieties of grapes (Vitis vinifera) [45]. On the other hand, Cabernet Franc and Cabernet Sauvignon were introduced to Georgia from France [46]. High quality red table wine is produced from Cabernet Franc and Cabernet Sauvignon in Telavi (Georgia). Rkatsiteli and Saperavi represent some of the oldest grape varieties and have consistently been the most important in Georgia's commercial winemaking industry. Rkatsiteli grapes are used for making European and Kakhetian-type white table wines as well as strong (12-13\% (v/v) alcohol) and dessert wines. High quality red table wine is produced from Saperavi grapes while Tavkveri is an indigenous red grape variety of Georgia. Tavkveri grapes as well as being consumed as a fruit are associated with the production of bright red original wines $[45,46]$.

\section{Chemical constituents}

Compositional analysis of the different wines showed significant variation in their constituents (Table 1). The total acidity of the wines varied between $4.85 \pm 0.24 \mathrm{~g} \mathrm{~L}^{-1}$ for Rkatsiteli 2017 and $6.31 \pm 0.30 \mathrm{~g} \mathrm{~L}^{-1}$ for Tavkveri 2017 (Table 1). According to Lučan and Palič the amounts of total acids in 38 different wines ranged between $3-11 \mathrm{~g} \mathrm{~L}^{-1}$, [47].

The alcohol content of the tested wines ranged from $12.50 \pm 0.61$ to $14.50 \pm 0.02 \%$ (v/v). King et al., 2013 [30] reported that alcohol level in Cabernet Sauvignon wines ranged from $12 \% \mathrm{v} / \mathrm{v}$ to $16 \% \mathrm{v} / \mathrm{v}$.

Cabernet Sauvignon 2017 and Cabernet Franc 2017 had the highest total polyphenolic content, i.e., $1843.13 \pm 92.15$ and $1650.82 \pm 82.50 \mathrm{mg} \mathrm{L}^{-1}$, respectively. Rkatsiteli 2017 had the lowest polyphenol content $-\left(1046.42 \pm 52.30 \mathrm{mg} \mathrm{L}^{-1}\right)$. The polyphenol contents of the other wines ranged between $1087.63 \pm 54.35$ and $1197.00 \pm 59.85 \mathrm{mg} \mathrm{L}^{-1}$ (Table 1). Cabernet Sauvignon 2017 also had the highest content of dry matter and monomeric anthocyanins, i.e., $26.50 \pm 1.32 \mathrm{~g} \mathrm{~L}^{-1}$ and $484.18 \pm 24.20 \mathrm{mg} \mathrm{L}^{-1}$, respectively. The dry matter content of the other wines was found to be between $19.00 \pm 0.92$ and $22.50 \pm 1.12 \mathrm{~g} \mathrm{~L}^{-1}$. Tavkveri $2017 \mathrm{had}$ the lowest level of dry extract $19.00 \pm 0.92 \mathrm{~g} \mathrm{~L}^{-1}$. For comparison, analyses of Brazilian wines showed that dry extract content in average was $21 \mathrm{~g} / \mathrm{l}$. [48].Cabernet Franc 2017 had the second highest level $\left(426.12 \pm 21.30 \mathrm{mg} \mathrm{L}^{-1}\right)$ of anthocyanins. The lowest content of anthocyanin was observed for Saperavi $2016\left(175.05 \pm 8.75 \mathrm{mg} \mathrm{L}^{-1}\right)$. Tavkveri 2017 and Saperavi 2017 had intermediate anthocyanin levels, i.e., $303.43 \pm 15.17$ and $231.13 \pm 11.55$ 
$\mathrm{mg} \mathrm{L}^{-1}$, respectively. These results are in good agreement with literature values which report that total polyphenol and anthocyanin content in wines ranges between 177-3477 mg $\mathrm{L}^{-1}$ and $11.25-1570 \mathrm{mg} \mathrm{L}^{-1}$, respectively [49].

Proximate chemical composition of wines*

Table 1

\begin{tabular}{|c|c|c|c|c|c|c|}
\hline & 1 & 2 & 3 & 4 & 5 & 6 \\
\hline $\begin{array}{l}\mathrm{TA} \\
\mathrm{gL}^{-1}\end{array}$ & $\begin{array}{c}5.85 \\
\pm 0.29^{\mathrm{a}} \\
\end{array}$ & $\begin{array}{c}4.89 \\
\pm 0.24^{\mathrm{b}} \\
\end{array}$ & $\begin{array}{c}6.31 \\
\pm 0.30^{\mathrm{c}}\end{array}$ & $\begin{array}{c}5.41 \\
\pm 0.26^{\mathrm{d}}\end{array}$ & $\begin{array}{c}5.40 \\
\pm 0.25^{\mathrm{d}}\end{array}$ & $\begin{aligned} & 4.85 \\
\pm & 0.24^{\mathrm{b}}\end{aligned}$ \\
\hline $\begin{array}{l}\text { Non-volatile dry extract, } \\
\mathrm{gL}^{-1}\end{array}$ & $\begin{array}{r}22.00 \\
\pm 1.10^{\mathrm{a}}\end{array}$ & $\begin{array}{r}22.50 \\
\pm 1.12^{\mathrm{a}} \\
\end{array}$ & $\begin{array}{r}19.00 \\
\pm 0.92^{b}\end{array}$ & $\begin{array}{r}23.70 \\
\pm 1.18^{\mathrm{a}}\end{array}$ & $\begin{array}{r}26.50 \\
\pm 1.32^{\mathrm{c}}\end{array}$ & $\begin{array}{r}20.50 \\
\pm 1.25^{\mathrm{d}}\end{array}$ \\
\hline $\begin{array}{l}\text { Total polyphenols GAE, } \\
\mathrm{mgL}^{-1}\end{array}$ & $\begin{array}{l}1142.58 \\
\pm 57.12^{\mathrm{a}} \\
\end{array}$ & $\begin{array}{l}1197.00 \\
\pm 59.85^{\mathrm{a}}\end{array}$ & $\begin{array}{l}1087.63 \\
\pm 54.35^{\mathrm{a}} \\
\end{array}$ & $\begin{array}{l}1650.82 \\
\pm 82.50^{\mathrm{b}}\end{array}$ & $\begin{array}{l}1843.13 \\
\pm 92.15^{\mathrm{c}} \\
\end{array}$ & $\begin{array}{l}1046.42 \\
\pm 52.30^{\mathrm{a}} \\
\end{array}$ \\
\hline $\begin{array}{l}\text { FRAP, } \\
\mathrm{mg} \mathrm{AAE} \cdot \mathrm{L}^{-1}\end{array}$ & $\begin{array}{l}1466.66 \\
\pm 73.33^{\mathrm{a}}\end{array}$ & $\begin{array}{l}1385.82 \\
\pm 69.29^{\mathrm{a}}\end{array}$ & $\begin{array}{l}1396.82 \\
\pm 68.44^{\mathrm{a}}\end{array}$ & $\begin{array}{l}1973.09 \\
\pm 98.65^{\mathrm{b}}\end{array}$ & $\begin{array}{l}2189.05 \\
\pm 109.45^{\mathrm{c}}\end{array}$ & $\begin{array}{l}1043.89 \\
\pm 52.19^{\mathrm{a}}\end{array}$ \\
\hline $\begin{array}{l}\text { Monomeric anthocyanins, } \\
\mathrm{mgL}^{-1}\end{array}$ & $\begin{array}{l}175.05 \\
\pm 8.75^{\mathrm{a}}\end{array}$ & $\begin{array}{l}231.13 \\
\pm 11.55^{\mathrm{b}}\end{array}$ & $\begin{array}{l}303.43 \\
\pm 15.17^{\mathrm{c}}\end{array}$ & $\begin{array}{l}426.12 \\
\pm 21.30^{\mathrm{d}}\end{array}$ & $\begin{array}{l}484.18 \\
\pm 24.20^{\mathrm{e}}\end{array}$ & $\mathrm{N} / \mathrm{A}$ \\
\hline $\begin{array}{l}\text { Alcohol content, } \\
\%\end{array}$ & $\begin{array}{c}13.50 \\
\pm 0.67^{\mathrm{a}}\end{array}$ & $\begin{array}{c}14.00 \\
\pm 0.71^{\mathrm{a}}\end{array}$ & $\begin{array}{c}13.00 \\
\pm 0.65^{\mathrm{a}}\end{array}$ & $\begin{array}{c}14.00 \\
\pm 0.70^{\mathrm{a}}\end{array}$ & $\begin{array}{l}14.50 \\
\pm 0.02^{\mathrm{a}}\end{array}$ & $\begin{array}{c}12.50 \\
\pm 0.612^{\mathrm{a}}\end{array}$ \\
\hline
\end{tabular}

1. Saperavi 2016;

2. Saperavi 2017;

3. Tavkveri 2017;

4. Cabernet Franc 2017;

5. Cabernet Sauvignon 2017;

6. Rkatsiteli 2017.

*-Values within a row with different letters are significantly different by ANOVA with Tukey's HSD tests at $\mathrm{p}<$ 0.05 .

\section{Individual polyphenols}

The individual polyphenolic compounds, caffeic acid, (-) epicatechin, $(+)$ catechin and gallic acid, were chromatographically separated and quantified. A typical reverse-phase HPLC separation profile, in the case of Cabernet Franc 2017, is shown in Fig 1. Highly significant differences in the four individual polyphenolic compounds quantified were observed in the wine samples analysed in this study. The highest content of caffeic acid was present in Saperavi $2016\left(17.3 \pm 0.86 \mathrm{mg} \mathrm{L}^{-1}\right)$ and the lowest was in Tavkveri 2017 $\left(1.80 \pm 0.09 \mathrm{mg} \mathrm{L}^{-1}\right)$ and Rkatsiteli $2017\left(2.00 \pm 0.10 \mathrm{mgL}^{-1}\right)$. Cabernet Franc 2017, Saperavi 2017 and Cabernet sauvignon 2017 contained $3.50 \pm 0.017,11.60 \pm 0.58$ and $4.00 \pm 0.20 \mathrm{mg}$ $\mathrm{L}^{-1}$ caffeic acid, respectively (Table 2). According to Šeruga et al. 2011 [50,] content of caffeic acid in some Croatian wines varied between $3-18 \mathrm{mg} \mathrm{L}^{-1}$.

(-) Epicatechin was present in highest content in Cabernet Sauvignon 2017 $\left(44.70 \pm 2.23 \mathrm{mg} \mathrm{L}^{-1}\right)$ and Cabernet Franc $2017\left(36.60 \pm 1.83 \mathrm{mg} \mathrm{L}^{-1}\right)$. The lowest content of (-) epicatechin was found in Tavkveri $2017\left(3.70 \pm 0.18 \mathrm{mg} \mathrm{L}^{-1}\right)$ and Saperavi 2016 $\left(9.50 \pm 0.47 \mathrm{mg} \mathrm{L}^{-1}\right)$. Saperavi 2017 and Rkatsiteli 2017 contained $16.80 \pm 0.84$ and $12.80 \pm 0.64 \mathrm{mg} \mathrm{L}^{-1}(-)$ epicatechin, respectively (Table 2) The same authors [50] reported that content of (-) Epicatechin in Croatian wines was in range of 7-37 $\mathrm{mg} \mathrm{L}^{-1}$. 
Individual polyphenols in wines*

\begin{tabular}{|l|c|c|c|c|c|c|}
\hline \multirow{2}{*}{$\begin{array}{l}\text { Individual } \\
\text { polyphenols }\end{array}$} & \multicolumn{7}{|c|}{$\mathbf{m g L}^{-1}$} \\
\cline { 2 - 7 } & $\mathbf{1}$ & $\mathbf{2}$ & $\mathbf{3}$ & $\mathbf{4}$ & $\mathbf{5}$ & $\mathbf{6}$ \\
\hline Caffeic acid & 17.30 & 11.60 & 1.80 & 3.50 & 4.00 & 2.00 \\
& $\pm 0.86^{\mathrm{a}}$ & $\pm 0.58^{\mathrm{b}}$ & $\pm 0.09^{\mathrm{c}}$ & $\pm 0.17^{\mathrm{d}}$ & $\pm 0.20^{\mathrm{e}}$ & $\pm 0.10^{\mathrm{f}}$ \\
\hline (-)- & 9.50 & 16.80 & 3.70 & 36.60 & 44.70 & 12.80 \\
Epycatechin & $\pm 0.47^{\mathrm{a}}$ & $\pm 0.84^{\mathrm{b}}$ & $\pm 0.18^{\mathrm{c}}$ & $\pm 1.83^{\mathrm{d}}$ & $\pm 2.23^{\mathrm{e}}$ & $\pm 0.64^{\mathrm{f}}$ \\
\hline (+)-Catechin & 9.00 & 11.80 & 5.30 & 11.70 & 30.00 & 46.20 \\
& $\pm 0.45^{\mathrm{a}}$ & $\pm 0.59^{\mathrm{b}}$ & $\pm 0.26^{\mathrm{c}}$ & $\pm 0.58^{\mathrm{b}}$ & $\pm 1.50^{\mathrm{d}}$ & $\pm 2.31^{\mathrm{e}}$ \\
\hline Gallic acid & 4.80 & 10.00 & 3.50 & 20.20 & 21.00 & 9.40 \\
& $\pm 0.24^{\mathrm{a}}$ & $\pm 0.50^{\mathrm{b}}$ & $\pm 0.17^{\mathrm{a}}$ & $\pm 1.01^{\mathrm{c}}$ & $\pm 1.05^{\mathrm{c}}$ & $\pm 0.47^{\mathrm{b}}$ \\
\hline
\end{tabular}

1. Saperavi 2016;

2. Saperavi 2017;

3. Tavkveri 2017;
4. Cabernet Franc 2017;

5. Cabernet Sauvignon 2017;

6. Rkatsiteli 2017.

*-Values within a row with different letters are significantly different by ANOVA with Tukey's HSD tests at $\mathrm{p}<0.05$.

As to the $(+)$ catechinen the authors [50] found it to be between $31-138 \mathrm{mg} \mathrm{L}^{-1}$. According to our analyses the content of $(+)$ catechin was highest in Rkatsiteli 2017 and Cabernet Sauvignon 2017 (46.20 2.31 and $30.00 \pm 1.50 \mathrm{mg} \mathrm{L}^{-1}$, respectively). Tavkveri 2017 and Saperavi 2016 had the lowest content of $(+)$ catechin $\left(5.30 \pm 0.26 \mathrm{mg} \mathrm{L}^{-1}\right.$ and $9.00 \pm 0.45 \mathrm{mg} \mathrm{L}^{-1}$, respectively). Saperavi 2017 and Cabernet Franc 2017 had similar levels of $(+)$ catechins, i.e., $11.80 \pm 0.59$ and $11.70 \pm 0.58 \mathrm{mg} \mathrm{L}^{-1}$, respectively (Table 2).

The highest content of gallic acid was observed in Cabernet Sauvignon 2017 (21.00 $\left.\pm 1.05 \mathrm{mg} \mathrm{L}^{-1}\right)$ and Cabernet Franc $2017\left(20.20 \pm 1.01 \mathrm{mg} \mathrm{L}^{-1}\right)$. Saperavi 2017 and Rkatsiteli 2017 had intermediate levels of gallic acid, i.e., $11.80 \pm 0.59$ and $9.40 \pm 0.47 \mathrm{mg} \mathrm{L}^{-1}$, respectively. The lowest content of gallic acid was found in Tavkveri $2017(3.50 \pm 0.17 \mathrm{mg}$ $\left.\mathrm{L}^{-1}\right)$ and Saperavi $2016\left(4.80 \pm 0.24 \mathrm{mg} \mathrm{L}^{-1}\right.$, Table 2). Gallic acid content in Chilean Cabernet Sauvignon was found to be $22.2 \mathrm{mg} \mathrm{L}^{-1}$. In some other wines gallic acid content varied from $7.8 \mathrm{mg} \mathrm{L}^{-1}$ up to $70.8 \mathrm{mg} \mathrm{L}^{-1}$ [51].

Other individual polyphenols were not identified within this study due to a lack of corresponding standards.

\section{Content of individual anthocyanins}

As already outlined, individual anthocyanins were separated, identified and quantified using LC-MS. In concurrence with the observed differences in monomeric anthocyanins (Table 1) the content of the individual anthocyanins varied significantly depending of the wine sample analysed (Table 3 ). 
Table 3

Individual anthocyanins in wines*

\begin{tabular}{|c|c|c|c|c|c|}
\hline \multirow[t]{2}{*}{ Anthocyanins } & \multicolumn{5}{|c|}{$\%$} \\
\hline & 1 & 2 & 3 & 4 & 5 \\
\hline $\begin{array}{l}\text { Delphinidin-3-O- } \\
\text { monoglucoside }\end{array}$ & $\begin{array}{c}1.87 \\
\pm 0.07^{\mathrm{a}}\end{array}$ & $\begin{array}{c}1.61 \\
\pm 0.04^{\mathrm{b}}\end{array}$ & $\begin{array}{c}2.13 \\
\pm 0.10^{\mathrm{c}}\end{array}$ & $\begin{array}{c}1.41 \\
\pm 0.06^{\mathrm{d}}\end{array}$ & $\begin{array}{c}1.16 \\
\pm 0.006^{\mathrm{e}}\end{array}$ \\
\hline $\begin{array}{l}\text { Cyanidin-3-O- } \\
\text { monoglucoside }\end{array}$ & $\begin{array}{c}0.15 \\
\pm 0.01^{\mathrm{a}}\end{array}$ & $\begin{array}{c}0.15 \\
\pm 0.005^{\mathrm{a}}\end{array}$ & $\begin{array}{c}0.14 \\
\pm 0.001^{\mathrm{a}}\end{array}$ & $\begin{array}{c}0.06 \\
\pm 0.003^{\mathrm{c}}\end{array}$ & $\begin{array}{c}0.18 \\
\pm 0.008^{\mathrm{d}}\end{array}$ \\
\hline $\begin{array}{l}\text { Petunidin-3-O- } \\
\text { monoglucoside }\end{array}$ & $\begin{array}{c}4.50 \\
\pm 0.10^{\mathrm{a}}\end{array}$ & $\begin{array}{c}5.29 \\
\pm 0.28^{\mathrm{b}}\end{array}$ & $\begin{array}{c}5.67 \\
\pm 0.27^{\mathrm{b}}\end{array}$ & $\begin{array}{c}2.70 \\
\pm 0.13^{\mathrm{c}}\end{array}$ & $\begin{array}{c}2.07 \\
\pm 0.10^{\mathrm{d}}\end{array}$ \\
\hline $\begin{array}{l}\text { Peonidin-3-O- } \\
\text { monoglucoside }\end{array}$ & $\begin{array}{c}3.04 \\
\pm 0.09^{\mathrm{a}}\end{array}$ & $\begin{array}{c}2.34 \\
\pm 0.13^{\mathrm{b}}\end{array}$ & $\begin{array}{c}2.50 \\
\pm 0.12^{\mathrm{b}}\end{array}$ & $\begin{array}{c}3.97 \\
\pm 0.19^{\mathrm{c}} \\
\end{array}$ & $\begin{array}{c}2.51 \\
\pm 0.12^{\mathrm{b}}\end{array}$ \\
\hline $\begin{array}{l}\text { Malvidin-3-O- } \\
\text { monoglucoside }\end{array}$ & $\begin{array}{r}60.67 \\
\pm 3.45^{\mathrm{a}}\end{array}$ & $\begin{array}{r}63.59 \\
\pm 3.78^{b}\end{array}$ & $\begin{array}{r}68.58 \\
\pm 3.43^{\mathrm{c}}\end{array}$ & $\begin{aligned} 50.21 \\
\pm 2.32^{\mathrm{d}}\end{aligned}$ & $\begin{array}{l}48.12 \\
\pm 2.40^{\mathrm{d}}\end{array}$ \\
\hline $\begin{array}{l}\text { Delphinidin-3,5-O- } \\
\text { diglucoside }\end{array}$ & $\begin{array}{c}7.91 \\
\pm 0.28^{\mathrm{a}}\end{array}$ & $\begin{aligned} & 3.50 \\
\pm & 0.25^{\mathrm{b}}\end{aligned}$ & $\begin{array}{c}2.13 \\
\pm 0.01^{\mathrm{c}}\end{array}$ & $\begin{array}{c}2.47 \\
\pm 0.12^{\mathrm{d}}\end{array}$ & $\begin{array}{c}2.31 \\
\pm 0.28^{\mathrm{d}}\end{array}$ \\
\hline $\begin{array}{l}\text { Petunidin-3-O- } \\
\text { acetylmonoglucoside }\end{array}$ & $\begin{array}{c}0.77 \\
\pm 0.03^{\mathrm{a}} \\
\end{array}$ & $\begin{array}{c}0.64 \\
\pm 0.17^{\mathrm{b}}\end{array}$ & $\begin{array}{c}0.24 \\
\pm 0.01^{\mathrm{c}} \\
\end{array}$ & $\begin{array}{c}1.36 \\
\pm 0.06^{\mathrm{d}}\end{array}$ & $\begin{array}{c}2.30 \\
\pm 0.13^{\mathrm{e}} \\
\end{array}$ \\
\hline $\begin{array}{l}\text { Petunidin-3,5-O- } \\
\text { diglucoside }\end{array}$ & $\begin{array}{c}0.03 \\
\pm 0.001^{\mathrm{a}}\end{array}$ & $\begin{array}{c}0.05 \\
\pm 0.002^{\mathrm{b}}\end{array}$ & $\begin{aligned} & 0.02 \\
\pm & 0.001^{\mathrm{c}}\end{aligned}$ & $\begin{array}{c}0.10 \\
\pm 0.005^{\mathrm{d}}\end{array}$ & $\begin{array}{c}0.07 \\
\pm 0.002^{\mathrm{e}}\end{array}$ \\
\hline $\begin{array}{l}\text { Malvidin-3-O- } \\
\text { acetylmonoglucoside }\end{array}$ & $\begin{array}{c}4.95 \\
\pm 0.11^{\mathrm{a}}\end{array}$ & $\begin{array}{c}5.55 \\
\pm 0.26^{\mathrm{b}}\end{array}$ & $\begin{array}{c}6.68 \\
\pm 0.32^{\mathrm{c}}\end{array}$ & $\begin{array}{l}19.44 \\
\pm 0.97^{\mathrm{d}}\end{array}$ & $\begin{array}{l}26.65 \\
\pm 1.33^{\mathrm{e}}\end{array}$ \\
\hline $\begin{array}{l}\text { Peonidin } \\
-3,5-O \text {-diglucoside }\end{array}$ & $\begin{array}{c}0.06 \\
\pm 0.003^{\mathrm{a}} \\
\end{array}$ & $\begin{array}{c}0.01 \\
\pm 0.001^{\mathrm{b}} \\
\end{array}$ & $\begin{array}{c}0.02 \\
\pm 0.001^{\mathrm{c}} \\
\end{array}$ & $\begin{array}{c}0.06 \\
\pm 0.003^{\mathrm{d}} \\
\end{array}$ & $\begin{array}{c}0.26 \\
\pm 0.01^{\mathrm{e}} \\
\end{array}$ \\
\hline $\begin{array}{l}\text { Malvidin-3-(6-O- } \\
\text { caffeoyl) } \\
\text { monoglucoside }\end{array}$ & $\begin{array}{c}1.68 \\
\pm 0.08^{\mathrm{a}}\end{array}$ & $\begin{array}{c}1.13 \\
\pm 0.05^{\mathrm{b}}\end{array}$ & $\begin{array}{c}0.40 \\
\pm 0.02^{\mathrm{c}}\end{array}$ & $\begin{array}{c}0.50 \\
\pm 0.02^{\mathrm{d}}\end{array}$ & $\begin{array}{c}0.47 \\
\pm 0.02^{\mathrm{d}}\end{array}$ \\
\hline $\begin{array}{l}\text { Petunidin-3-(6-O-p- } \\
\text { coumaroyl) } \\
\text { monoglucoside }\end{array}$ & $\begin{array}{c}0.32 \\
\pm 0.01^{\mathrm{a}}\end{array}$ & $\begin{array}{c}0.68 \\
\pm 0.02^{\mathrm{b}}\end{array}$ & $\begin{array}{c}0.74 \\
\pm 0.03^{\mathrm{c}}\end{array}$ & $\begin{array}{c}0.57 \\
\pm 0.02^{\mathrm{d}}\end{array}$ & $\begin{array}{c}0.34 \\
\pm 0.01^{\mathrm{a}}\end{array}$ \\
\hline $\begin{array}{l}\text { Malvidin-3-(6-O-p- } \\
\text { coumaroyl),5-0- } \\
\text { diglucoside }\end{array}$ & $\begin{array}{c}0.22 \\
\pm 0.01^{\mathrm{a}}\end{array}$ & $\begin{array}{c}0.31 \\
\pm 0.01^{\mathrm{b}}\end{array}$ & $\begin{array}{c}0.40 \\
\pm 0.02^{\mathrm{c}}\end{array}$ & $\begin{array}{c}0.43 \\
\pm 0.02^{\mathrm{d}}\end{array}$ & $\begin{array}{c}0.42 \\
\pm 0.01^{\mathrm{d}}\end{array}$ \\
\hline $\begin{array}{l}\text { Peonidin-3-(6-O-p- } \\
\text { coumaroyl) } \\
\text { monoglucoside }\end{array}$ & $\begin{array}{c}0.76 \\
\pm 0.02^{\mathrm{a}}\end{array}$ & $\begin{array}{c}1.25 \\
\pm 0.06^{\mathrm{b}}\end{array}$ & $\begin{array}{c}0.90 \\
\pm 0.04^{\mathrm{c}}\end{array}$ & $\begin{array}{c}1.05 \\
\pm 0.02^{\mathrm{d}}\end{array}$ & $\begin{array}{c}0.50 \\
\pm 0.02^{\mathrm{e}}\end{array}$ \\
\hline $\begin{array}{l}\text { Malvidin-3-(6-O-p- } \\
\text { coumaroyl) } \\
\text { monoglucoside }\end{array}$ & $\begin{array}{c}7.18 \\
\pm 0.37^{\mathrm{a}}\end{array}$ & $\begin{array}{c}9.66 \\
\pm 0.47^{\mathrm{b}}\end{array}$ & $\begin{array}{c}5.26 \\
\pm 0.25^{\mathrm{c}}\end{array}$ & $\begin{array}{c}8.39 \\
\pm 0.41^{\mathrm{d}}\end{array}$ & $\begin{array}{c}6.29 \\
\pm 0.30^{\mathrm{e}}\end{array}$ \\
\hline $\begin{array}{l}\text { Delphinidin-3-(6-O- } \\
\text { p-coumaroyl) } \\
\text { monoglucoside }\end{array}$ & $\begin{array}{c}0.61 \\
\pm 0.03^{\mathrm{a}}\end{array}$ & $\begin{array}{c}0.85 \\
\pm 0.04^{\mathrm{b}}\end{array}$ & $\begin{array}{c}1.18 \\
\pm 0.05^{\mathrm{c}}\end{array}$ & $\begin{array}{c}1.81 \\
\pm 0.09^{\mathrm{d}}\end{array}$ & $\begin{array}{c}1.62 \\
\pm 0.08^{\mathrm{e}}\end{array}$ \\
\hline
\end{tabular}

1. Saperavi 2016;

2. Saperavi 2017;

3. Tavkveri 2017;

*- Values within a row with different letters are significantly different by ANOVA with Tukey's HSD tests at $\mathrm{p}<0.05$.
4. Cabernet Franc 2017;

5. Cabernet Sauvignon 2017 
Overall, malvidin-3-O-monoglucoside was the main anthocyanin present in all the wine samples analysed herein. The percentage, in terms of monomeric anthocyanin content, of malvidin-3-O-monoglucoside varied from $68.58 \pm 3.43 \%$ (Tavkveri 2017 ) to $48.12 \pm 2.40$ $\%$ (Cabernet Sauvignon 2017). The other main anthocyanins detected in the wines were malvidin-3-(6- $O$-p-coumaroyl) monoglucoside, malvidin-3- $O$-acetylmonoglucoside, petunidin-3- $O$-monoglucoside and peonidin-3- $O$-monoglucoside). Other anthocyanins were present in minor quantities. Similar results were obtained by María José Noriega and Ana Casp: 15 anthocyanins were identified in young red wines from appellation of origin Navarr (Spain). The 3-monoglucoside of malvidin was the major component in all of the wines. Its contribution to the total anthocyanin content ranged from $39,07 \%$ to nearly $70 \%$ [52].

\section{Lipase inhibition}

Cabernet Sauvignon 2017 and Cabernet Franc 2017 showed the highest level of lipase inhibition, i.e. $79.66 \pm 3.98$ and $78.79 \pm 2.45 \%$ per of $\mathrm{mL}$ of wine, respectively. These values were not statistically significantly $(\mathrm{p}<0.05)$ different (Table 4$)$.

Lipase activity and its inhibition by wines*

Table 4

\begin{tabular}{|l|c|c|c|c|c|c|}
\hline & $\mathbf{1}$ & $\mathbf{2}$ & $\mathbf{3}$ & $\mathbf{4}$ & $\mathbf{5}$ & $\mathbf{6}$ \\
\hline Inhibition \% based on 1 & 3.20 & 3.05 & 2.97 & 3.32 & 3.00 & 2.83 \\
mg dry matter & $\pm 0.16^{\mathrm{a}}$ & $\pm 0.14^{\mathrm{a}}$ & $\pm 0.14^{\mathrm{b}}$ & $\pm 0.18^{\mathrm{c}}$ & $\pm 0.15^{\mathrm{a}}$ & $\pm 0.14^{\mathrm{b}}$ \\
\hline Inhibition \% & 70.57 & 68.80 & 56.55 & 78.79 & 79.66 & 58.05 \\
& $\pm 3.52^{\mathrm{a}}$ & $\pm 3.44^{\mathrm{a}}$ & $\pm 2.82^{\mathrm{b}}$ & $\pm 2.45^{\mathrm{c}}$ & $\pm 3.98^{\mathrm{c}}$ & $\pm 2.90^{\mathrm{b}}$ \\
\hline Enzyme activity (Unit) & 2234.00 & 2369.00 & 3299.00 & 1544.00 & 1610.00 & 3185.00 \\
& $\pm 111.7^{\mathrm{a}}$ & $\pm 118.45^{\mathrm{a}}$ & $\pm 164.95^{\mathrm{b}}$ & $\pm 77.20^{\mathrm{d}}$ & $\pm 80.5^{\mathrm{c}}$ & $\pm 159.25^{\mathrm{e}}$ \\
\hline
\end{tabular}

1. Saperavi 2016;

4. Cabernet Franc 2017;

2. Saperavi 2017;

5. Cabernet Sauvignon 2017;

3. Tavkveri 2017;

6. Rkatsiteli 2017.

*- Values within a row with different letters are significantly different by ANOVA with Tukey's HSD tests at $\mathrm{p}<0.05$.

Saperavi 2016 and Saperavi 2017 showed the next highest level of lipase inhibition, i.e. $70.57 \pm 3.52$ and $68.80 \pm 3.44 \%$ per of $\mathrm{mL}$ of wine, respectively (again these values were not statistically significantly differeent). Rkatsiteli 2017 and Tavkveri 2017 had similar $(\mathrm{p}>0.05)$ and the lowest anti-lipase activity, i.e., $58.05 \pm 2.90$ and $56.55 \pm 2.82 \%$, respectively. Orlistat ${ }^{\circledR}(20 \mathrm{mg})$ showed $83 \%$ inhibition of lipase activity. Furthermore, the $\mathrm{r}^{2}$ correlation value between the polyphenol content and anti-lipase activity was 0.77 (Figure 1). A similar correlation was found between the decrease in in vivo lipid levels promoted by red wine (Cabernet Franc, Meriot, Sangiovese and Syrah 2006 and 2007 from southern Brazil) consumption and the content of stilbens and tyrosol, a special class of polyphenols [53]. Some differences in the results for anti-lipase activities were observed when calculated per mg dry extract. Cabernet Franc 2017 and Saperavi 2016 showed the highest anti-lipase activity, i.e., $3.32 \pm 0.18$ and $3.20 \pm 0.16 \%$, respectively. Tavkveri 2017, Saperavi 2017 and Cabernet Sauvignon had approx. 3\% lipase inhibitory activity. Rkatsiteli 
2017 possessed the lowest anti-lipase activity, i.e., $2.83 \pm 0.14 \%$. The anti-lipase activity of Orlistat ${ }^{\circledR}$ calculated per $\mathrm{mg}$ of the preparation was equal to $4.2 \%$. These data show that the anti-lipase activity of Cabernet Franc 2017 and Saperavi 2016 was only $21.4 \%$ less than that of Orlistat ${ }^{\circledR}$. According to Jaradat et al., 2017 [54] the aqueous extract of $V$. vinifera had lipase $\mathrm{IC}_{50}$ value of $14.13 \mu \mathrm{g} \mathrm{mL}^{-1}$ while Orlistat had a $\mathrm{IC}_{50}$ value of $12.38 \pm 2.3$ $\mu \mathrm{g} \mathrm{mL} \mathrm{L}^{-1}$.

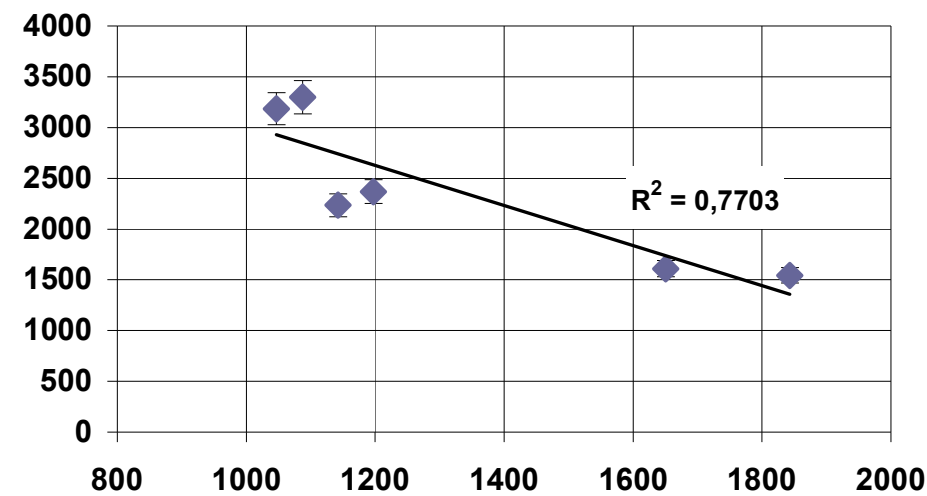

Figure 1. Correlation between enzyme activity and TPC

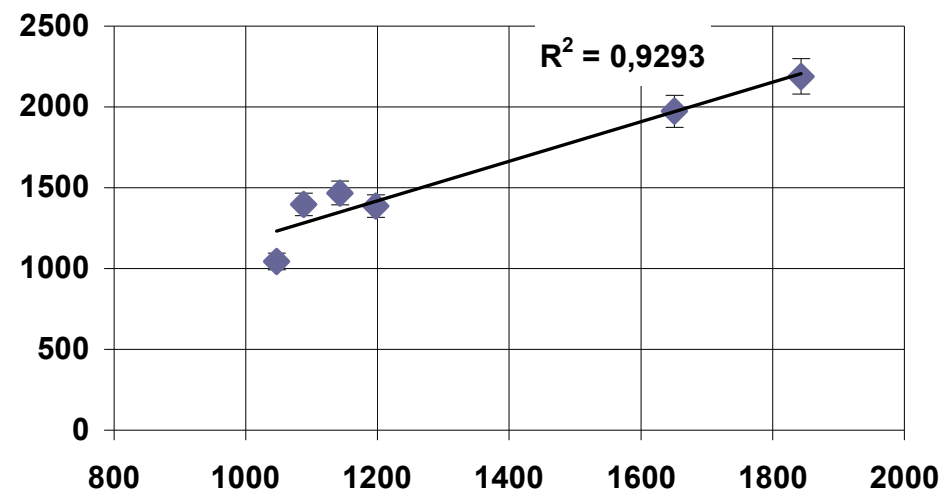

Figure 2. Correlation between FRAP and TPC

\section{Antioxidant activity}

According to literature reports, the antioxidant activity of wine varies between 879.12 - $2304.36 \mathrm{mg} \mathrm{AAE} \cdot \mathrm{L}^{-1}$ [55-56]. For the wines studied herein, Cabernet Sauvignon 2017 and Cabernet Franc 2017 displayed the highest antioxidant activity i.e., $2189.05 \pm 109.45$ and 1973.09 \pm 98.65 FRAP $\mathrm{mg}$ AAE $\cdot \mathrm{L}^{-1}$, respectively. Rkatsiteli 2017 contained the lowest antioxidant activity $\left(1043.89 \pm 52.19\right.$ FRAP $\left.\mathrm{mg} \mathrm{AAE} \cdot \mathrm{L}^{-1}\right)$. The observed higher level of antioxidant activity in red as opposed to white wine is in agreement with the trends reported in the literature [57]. There were no statistically significant differences $(p>0.05)$ between the antioxidant activities of Saperavi 2016, Saperavi 2017 and Tavkveri 2017. Their antioxidant activities ranged from $1385.82 \pm 69.29$ to $1466.66 \pm 73.33$ FRAP mg AAE $\cdot \mathrm{L}^{-1}$. 
There was a good correlation $\left(\mathrm{r}^{2}=0.93\right)$ between the polyphenol content in wines and their antioxidant activities (Figure 2). For comparison, a significantly positive correlation was reported between the antioxidant activity of Spanish wines and the total phenols or the total anthocyanins [49].

\section{Conclusion}

The red and white wines produced in Georgia from different varieties of Vitis vinifera have high anti-lipase activity when compared to Orlistat ${ }^{\circledR}$, a synthetic drug compound used in the treatment of obesity. A correlation appeared to exist between the anti-lipase and antioxidant activity of the wines and their polyphenol content The main anthocyanin present in red wines wass malvidin-3-O-monoglucoside. Georgian red and white wines may be considered as a suitable natural sources for the extraction of compounds with high antilipase activity. The potential anti-obesity properties of these compounds merits further study in vitro and ultimately in vivo.

Acknowledgement. The research was carried out in the framework of the research project: "Development of new formulation for high specific natural inhibitor of pancreatic lipase" financed by Shota Rustaveli National Science Foundation (SRNSF), no. 217416.

\section{References}

1. (2018), Obesity and overweight, http://www.who.int/mediacentre/factsheets/fs311/en

2. Birari R.B., Bhutani K.K. (2007), Pancreatic lipase inhibitors from natural sources: unexplored potential, Drug Discovery Today, DOI: 10.1016/j.drudis.2007.07.024

3. Gurmeet KSS., Rosnah I., Normadiah MK., Das S., Mustafa AM. (2014), Detrimental effects of bisphenol A on development and functions of the male reproductive system in experimental rats, Experimental and Clinical Sciences, 13, pp. 151-160.

4. Lunagariya N.A., Patel N.K., Jagtap S.C. Bhutani K.K. (2014), Inhibitors of pancreatic lipase: state of the art and clinical perspectives, EXCLI Journal Experimental and Clinical Sciences, 13, pp. 897-921.

5. Slanc P., Doljak B., Kreft S., Lunder M., Janes D., Strukelj B. (2009), Screening of selected food and medicinal plant extracts for pancreatic lipase inhibition, Phytotherapy Research, DOI: 10.1002/ptr.2718.

6. Zheng C.D., Duan Y.Q., Gao J.M., Ruan, Z.G. (2010), Screening for anti-lipase properties of 37 traditional Chinese medicinal herbs, Journal of the Chinese Medical Association, DOI: 10.1016/S1726-4901(10)70068-X.

7. Seyedan A., Alshawsh M.A., Alshagga M.A., Koosha S., Mohamed Z. (2015), Medicinal Plants and Their Inhibitory Activities against Pancreatic Lipase: A Review, Hindawi Publishing Corporation, Evidence-Based Complementary and Alternative Medicine, DOI: http://dx.DOI.org/10.1155/2015/973143

8. Satouchi K., Kodama Y., Murakami K., Tanaka T., Iwamoto H., Ishimoto M. (2002), A Lipaseinhibiting Protein from Lipoxygenase-deficient Soybean Seeds, Bioscience, Biotechnology, and Biochemistry, DOI: 10.1271/bbb.66.2154

9. Terra X., Montagut G., Bustos M., Llopiz N., Ardvol A., Blad C. (2009), Grape-seed procyanidins prevent low-grade inflammation by modulating cytokine expression in rats fed a high-fat diet. The Journal of Nutritional Biochemistry, DOI: 10.1016/j.jnutbio.2008.02.005 
10. Quesada H., del Bas J.M., Pajuelo D., Diaz S., Fernandez-Larrea J., Pinent M., Arola L., Salvadó M.J., Bladé C. (2009), Grape seed proanthocyanidins correct dyslipidemia associated with a high-fat diet in rats and repress genes controlling lipogenesis and VLDL assembling in liver, International journal obesity, DOI: 10.1038/ijo.2009.136

11. GonDOIn A., Grussu D., Stewart D., McDougall G.J. (2010), White and green tea polyphenols inhibit pancreatic lipase in vitro. Food Research International, DOI: https://DOI.org/10.1016/j.foodres.2010.04.029

12. Cha K.H., Song D.G., Kim S.M., Pan CH. (2012), Inhibition of Gastrointestinal Lipolysis by Green Tea, Coffee, and Gomchui (Ligularia fischeri) Tea Polyphenols during Simulated Digestion, Journal of Agricultural and Food Chemistry, DOI: 10.1021/jf301047f

13. Ado M. A., Abas F., Mohammed A. S., Ghazali H. M. (2013), Anti and pro-lipase activity of selected medicinal, herbal and aquatic plants, and structure elucidation of an anti-lipase compound, Molecules, DOI: 10.3390/molecules181214651

14. Maqsood M., Ahmed D., Atique I., Malik W. (2017), Lipase inhibitory activity of Lagenaria siceraria fruit as a strategy to treat obesity, Asian Pacific Journal of Tropical Medicine, DOI: 10.1016/j.apjtm.2017.03.010

15. Sellami M., Louati H., Kamoun J., Kchaou A., Damak M., Gargouri Y. (2017), Inhibition of pancreatic lipase and amylase by extracts of different spices and plants, International Journal of Food Sciences and Nutrition, DOI: 10.1080/09637486.2016.1237479

16. He Q., Lev Y., Yao K. (2007), Effects of tea polyphenols on the activities of $\alpha$-amylase, pepsin, trypsin and lipase, Food Chemistry, DOI: 10.1016/j.foodchem.2006.03.020

17. Garza A.L., Milagro F.I., Boque N., Campión J., Martínez J.A. (2011), Natural inhibitors of pancreatic lipase as new players in obesity treatment, Planta medica, DOI: 10.1055/s-00301270924.

18. Sergent T., Vanderstraeten J., Winand J., Beguin P., Schneider I.J. (2012), Phenolic compounds and plant extracts as potential natural anti-obesity substances, Food Chemistry, DOI: https://DOI.org/10.1016/j.foodchem.2012.04.074

19. Wu X. He, W. Zhang H. Li Y. Liu Z. He, Z. (2014), Acteoside: A lipase inhibitor from the Chinese tea Ligustrum purpurascens kudingcha, Food Chemistry, DOI: 10.1016/j.foodchem.2013.07.071

20. Buchholz T., Melzig M.F. (2015), Polyphenolic Compounds as Pancreatic Lipase Inhibitors, Planta medica, DOI: $10.1055 / \mathrm{s}-0035-1546173$

21. Danış O., Ogan A., Anbar D., Dursun B.Y., Demir S., Salan U. (2015), Inhibition of Pancreatic Lipase by Culinary Plant Extracts, International Journal of Plant Biology \& Research, 3(2), p. 1038.

22. Dechakhamphu A., Wongchum N. (2015), Screening for anti-pancreatic lipase properties of 28 traditional Thai medicinal herbs, Asian Pacific Journal of Tropical Biomedicine, DOI: DOI.org/10.1016/j.apjtb.2015.09.012

23. Pan H., Gao Y., Tu Y. (2016), Mechanisms of Body Weight Reduction by Black Tea Polyphenols, Molecules, DOI: 10.3390/molecules21121659

24. Martinez-Gonzalez A.I., Alvarez-Parrilla E., Díaz-Sánchez A.G., de la Rosa L.A., NúñezGastélum J.A., Vazquez-Flores A.A., Gonzalez-Aguilar G.A. (2017), In vitro Inhibition of Pancreatic Lipase by Polyphenols: A Kinetic, Fluorescence Spectroscopy and Molecular Docking Study, Food Technology and Biotechnology, DOI: 10.17113/ftb.55.04.17.5138

25. Weigle D.S. (2003), Pharmacological therapy of obesity: past, present and future, The Journal of Clinical Endocrinology \& Metabolism, DOI: 10.1210/jc.2003-030151

26. Padwal R., Li S.K., Lau D.C. (2004), Long-term pharmacotherapy for obesity and overweight, The Cochrane Database of Systematic Reviews, DOI: 10.1002/14651858.CD004094.pub2

27. Ioannides-Demos L.L., Proietto J., Tonkin A.M., McNeil J.J. (2006), Safety of drug therapies used for weight loss and treatment of obesity, Drug safety, 29(4), pp. 277-302.

28. Singh A., Sarkar S.R., Gaber L.W., Perazella M.A. (2007), Acute oxalate nephropathy associated with orlistat, a gastrointestinal lipase inhibitor, American Journal of Kidney Diseases, DOI: $10.1053 /$ j.ajkd.2006.10.004 
27. Rucker D., Padwal R., Li S.K., Curioni C,. Lau D.C. (2007), Long term pharmacotherapy for obesity and overweight: updated metaanalysis, $B M J$, DOI:10.1136/bmj.39385.413113.25

30. King ES., Dunn RL., Heymann, H. (2013), The influence of alcohol on the sensory perception of red wines, Food Quality and Preference, 28, pp. 235-243.

31. Shalashvili A.,Targamadze I., Zambakhidze N., Chichua D., Nareklishvili V., Ugrekhelidze D. (2007), Comparision of wines of Kakhetian and European Types according to quantitative Content of Flavonoids and Antiradical Efficiency, Bulletin of the Georgian National Academy of Sciences, 175(4), pp. 102-105.

32. McGovern P., Jalabadze M., Batiuk S., Callahan M.P., Smith K.E., Hall G.R., Kvavadze E., Maghradze D., Rusishvili N., Bouby L., Failla O., Cola G., Mariani L., Boaretto E., Bacilieri R., This P.,Wales N., Lordkipanidze D. (2017), Early Neolithic wine of Georgia in the South Caucasus, Proceedings of the National Academy of Sciences, DOI: 10.1073/pnas.1714728114

33. Maghradze D., Samanishvili G., Mekhuzla L., Mdinaradze I., Tevzadze G., Aslanishvili A., Chavchanidze P., Lordkipanidze D., Jalabadze M., Kvavadze E., Rusishvili N., Nadiradze E., Archvadze G., McGovern P., This P., Bacilieri R., Failla O., Cola G., Mariani L., Wales N., Gilbert M.T.P. Bouby L. Kazeli T. Ujmajuridze L., Batiuk S., Graham A., Megrelidze L., Bagratia T., Davitashvili L. (2016), Grape and wine culture in Georgia, the South Caucasus, BIO Web of Conferences, DOI: 10.1051/bioconf/20160703027

34. Beridze T., Pipia I., Beck J., Hsuæ S.C., Gamkrelidze M., Gogniashvili M., Tabidze V., This P., Bacilieri R., Gotsiridze V., Glonti M., Schaal B. (2011), Plastid DNA Sequence Diversity in a Worldwide Set of Grapevine Cultivars (Vitis vinifera L. subsp. vinifera), Acta horticulturae, DOI: 10.17660/ActaHortic.2014.1046.84

35. Shalashvili A., Ugrekhelidze D., Mitaishvili T., Targamadze I., Zambakhidze N. (2012), Phenolic Compounds of Wines from Georgian Autochthonous Grapes, Rkatsiteli and Saperavi, Prepared by Georgian (Kakhetian) Technology, Bulletin of the Georgian National Academy of Sciences, 6(3), pp. 99-103.

36. Pipia I., Gogniashvili M., Tabidze V., Kotorashvili A., Kotaria N. (2015), Plastid DNA Sequence Diversity in Wild Grapevine Samples (Vitis vinifera subsp. sylvestris) from the Caucasus Region: Complete Plastid Genome Sequences of Three Georgian Samples, Acta Horticulturae, DOI: 10.17660/ActaHortic.2015.1082.29

37. Manna P., Sushil JK. (2015), Obesity, Oxidative Stress, Adipose Tissue, disfunction and the associated health risks: Causes and Therapeutic Strategies, Metabolic Syndrome and related disorders, 3 (10), https://DOI.org/10.1089/met.2015.0095

38. Navarre C., Langlade F. (2017), L'oenologie. Lavoisier/ Tec Et Doc. p. 433. ISBN 2743022744 (in French)

39. Gallander,J. (1987), Manual for wine analysis and laboratory techniques, Ohio State University, OARDC, Wooster, Ohio.

40. Resolution Oeno 566/2016. Method OIV MA AS312 01A, Alcoholic strength by volume (pycnometry, frequency oscillator, hydrostatic balance) (A2; 8/2000; 24/2003; revised by $377 / 2009$ ), Compendium of international methods of wine and must analysis, International Organisation of Vine and Wine, ISBN I: 979-10-91799-47-8.

41. Benzie I.F., Strain J.J. (1996), The ferric reducing ability of plasma (FRAP) as a measure of "antioxidant power": the FRAP assay. Analytical Biochemistry, DOI: 10.1006/abio.1996.0292

42. Bond T.J., Lewis J.R., Davis A., Davis A.P. (2003), Analysis and purification of catechins and their transformation products. In: SANTOS-BULGA, C., WILLIAMSON, G. (Eds.), Methods of polyphenols analysis. (p.258-266), London: The Royal Society of Chemistry, ISBN 0-85404580-5.

43. Giusti M.M., Wrolstad R.E. (2001), Current Protocols in Food Analytical Chemistry. In R.E. Wrolstad (Ed.), Unit F1.2.1 - 13. Anthocyanins. Characterization and Measurement with UV Visible Spectroscopy, New York. USA, John Wiley \& Sons.

44. Stoytcheva M., Gisela Montero G., Zlatev R., León J.A., Velizar Gochev V. (2012), Analytical Methods for Lipases Activity Determination: A Review, Current Analytical Chemistry, 8,pp. 400-407.

45. (2018) Georgian Federation of Artisan Wine Cellars, Available at: https://enoteca.ge/en. 
46. Maghradze D., Mdinaradze I., Chipashvili R., Abashidze E., Kikilashvili Sh., Baratashvili M., Vibliani M., Kharitonashvili L., Bitsadze N. (2017), Ampelographic Catalogue of Grape Varieties from Skra Collection.

47. Lučan Ž.D., Palič A. (1994), Total acids determination in wine with different methods, Molecular Nutrition, food research. 38(4), pp. 427-433.

48. Risson L.A., Miele A. (1996), Total dry extract in brazinian wines: comparison of analytical methods, Ciencia Rural, 26(2).

49. Han F., Jua Y., Ruana X., Zhao X., Yuea X., Zhuangb X., Qinb M., Fanga Y. (2017), Color, anthocyanin, and antioxidant characteristics of young wines produced from spine grapes (Vitis davidii Foex) in China. Food \& Nutrition Research, DOI: 10.1080/16546628.2017.1339552

50. Šeruga M., Novak I., Jakobek L. (2011), Determination of polyphenols content and antioxidant activity of some red wines by differential pulse voltammetry, HPLC and spectrophotometric methods, Food Chemistry, 124, pp. 1208-1216.

51. Burns J., Gardner P.T., O'Neil J., Crawford S., Morecroft I., McPhail D.B., Lister C., Matthews D., MacLean M.R., Lean M.E.m Duthie G.G.m Crozier A. (2000), Relationship among antioxidant activity, vasodilation capacity, and phenolic content of red wines, Journal of Agricultural and Food Chemistry, 48, pp. 220-230

52. Noriega M.J., Casp A. (2007), Anthocyanin characterization of young red wines from Appellation of origin Navarra (Spain), Journal International des Sciences de la Vigne et du Vin, 41(2), pp. 111-119.

53. Lim T. K. (2013), Edible Medicinal and Non-Medicinal Plant, Springer, p. 596, ISBN 978-94$007-5628-1$

54. Jaradat N., Zaid A.N., Hussein F., Zaqzouq M., Aljammal H., Ayesh O. (2017), Anti-Lipase Potential of the Organic and Aqueous Extracts of Ten Traditional Edible and Medicinal Plants in Palestine; a Comparison Study with Orlistat, Medicines, 4, 89; DOI:10.3390/medicines4040089

55. Pellegrini N., Serafini M., Colombi B., Rio D.D., Salvatore S., Bianchi M., Brighenti F. (2003), Total Antioxidant Capacity of Plant Foods, Beverages and Oils Consumed in Italy Assessed by Three Different In Vitro Assays, Journal of Nutrition, 133, pp. 2812-2819.

56. Gougoulias N., Papachatzis A., Kalorizou H. (2010), Studies of total phenol contents, anthocyans and antioxidant activity of some Greek red wines. Annals of the University of Craiova Series: Biology, Horticulturae, Food produce processing technology, Environmental engineering, XV(XLXI), pp. 269-274.

57. Stratil P., Vlastimil K., Jitka F. (2008), Comparison of the Phenolic Content and Total Antioxidant Activity in Wines as Determined by Spectrophotometric Methods, Czech Journal of Food Sciences, DOI: 10.17221/1119-CJFS 